\title{
Construction and Evaluation of Molecular Models: Guide and Design the Novel SE Inhibitors
}

Yunfei An ${ }^{\mathrm{a}}$, Yue Dong ${ }^{\mathrm{a}}$, Liu Min ${ }^{\mathrm{a}}$, Liyu Zhao ${ }^{\mathrm{b}}$, Dongmei Zhao ${ }^{\mathrm{b}}$, Jun Han ${ }^{\mathrm{a}}$, Bin Sun ${ }^{\mathrm{a}}$ *

${ }^{a}$ Institute of BioPharmaceutical Research, Liaocheng University, 1 Hunan Road, Liaocheng 252000, PR China

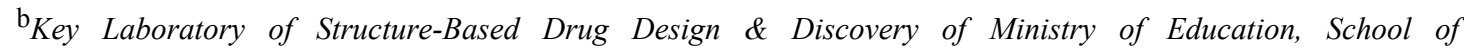
Pharmaceutical Engineering, Shenyang Pharmaceutical University, 103 Wenhua Road, Shenhe District, Shenyang 110016, PR China

\section{Experimental section}

General Methods for Chemistry

Unless otherwise noted, all commercial reagents and solvents were purchased and used without additional purification. Thin layer chromatography (TLC) analysis was performed on Silica Gel 60 F254 plates (Jiangyou, Yantai), which was used to monitor the reaction process. The silicagel (200-300 mesh) from Qingdao Ocean Chemicals (Qingdao, Shandong, China) was selected for column chromatography. The melting points of all compounds were determined and corrected with a Büchi Melting Point B-540 apparatus (Büchi Labortechnik, Flawil, Switzerland). Nuclear magnetic resonance $\left({ }^{1} \mathrm{H}-\mathrm{NMR}\right.$ and $\left.{ }^{13} \mathrm{C}-\mathrm{NMR}\right)$ spectra were recorded on a Bruker 600 $\mathrm{MHz}$ NMR spectrometer using TMS as an internal standard. Peak multiplicities were expressed as follows: s, singlet; d, doublet; $t$, triplet; q, quartet; dd, doublet of doublet; $\mathrm{dt}$, doublet of triplet; td, triplet of doublet; ddd, doublet of doublet of doublet; $\mathrm{m}$, multiplet; br, broad. The mass spectra (MS) were determined in ESI mode on an Shimadzu 8040 LC-MS (Shimadzu, Japan).

General procedure for the synthesis of amino acid ethyl ester hydrochloride (3)

L-amino acids (Glycine) (1.0 equiv) were dissolved in ethanol solution. Thionyl chloride (3.0 equiv) was slowly dripped into the mixed solution at $0{ }^{\circ} \mathrm{C}$ using ice salt bath. The mixture was heated to $65{ }^{\circ} \mathrm{C}$ for $6 \mathrm{~h}$. Then, the reaction mixture was concentrated under reduced pressure to give the white solid (3).

\subsection{General procedure for the synthesis of compounds (4a-d)}

The appropriate organic acids (1-naphthoic acid, 2-naphthoic acid, 2,3-dihyd robenzo[b][1,4]dioxine-5-carboxylic acid, 2,3-dihydrobenzo[b] [1,4]dioxine-6carboxylic acid, 1 equiv) and HATU (1.2 equiv) were added in anhydrous DMF, respectively. The mixture was stirred at room temperature for $2 \mathrm{~h}$. Then, amino acid ethyl ester hydrochloride (1.0 equiv) and DIEA (3.0 equiv) were added, the mixture was heated at $75{ }^{\circ} \mathrm{C}$ for $7 \mathrm{~h}$. The reaction process was monitored by TLC analysis. After the completion of reaction, the reaction mixture was poured into ice water, and extracted with ethyl acetate, the organic phase was dried over $\mathrm{Na}_{2} \mathrm{SO}_{4}$ overnight. Finally, the desired compounds were obtained by vacuum distillation.

General procedure for the synthesis of compounds (5a-d)

The compounds (4a-d; 1.0 equiv), $\mathrm{K}_{2} \mathrm{CO}_{3}$ (3 equiv) and $\mathrm{CH}_{3} \mathrm{I}$ (2 equiv) were dissolved in tetrahydrofuran. Then, the reaction mixture was stirred at $40{ }^{\circ} \mathrm{C}$ for $5 \mathrm{~h}$. The reaction process was monitored by TLC analysis. After the completion of reaction, the mixture was poured into ice water, and extracted with ethyl acetate, the 
organic phase was dried over $\mathrm{Na}_{2} \mathrm{SO}_{4}$ overnight. Finally, the desired compounds were obtained by vacuum distillation.

General procedure for the synthesis of compounds (6a-d)

The compounds (5a-d; 1 equiv) were dissolved in the $2 \mathrm{~N}$ sodium hydroxide (30 $\mathrm{mL})$ and methanol $(15 \mathrm{~mL})$ solution. Then, the reaction mixture was stirred at $60{ }^{\circ} \mathrm{C}$ for $2 \mathrm{~h}$. The reaction process was monitored by TLC analysis. After the completion of reaction, the methanol was removed by rotary evaporation, $\mathrm{pH}$ was adjusted to 1-2 by the dilute hydrochloric acid solution, and white solid was filtered and dried.

General procedure for the synthesis of target compounds (7a-d-1,2)

The key intermediate (6a-d; 1 equiv) and PyBOP (1.2 equiv) were added into the solution of DMF, respectively. The reaction mixture was stirred at room temperature for $2 \mathrm{~h}$. Then, the aniline or benzylamine (1.0 equiv) and DIEA ( 3 equiv) were added, the reaction mixture was heated at $80{ }^{\circ} \mathrm{C}$, and stirred for $7 \mathrm{~h}$. The reaction process was monitored by TLC analysis. After the completion of reaction, the reaction mixture was poured into ice water, the resulting solid was filtered and dried to give the desired compound. The crude product was purified by silica gel column chromatography $\left(\mathrm{CH}_{2} \mathrm{Cl}_{2}: \mathrm{MeOH}=100: 3\right)$.

N-methyl-N-(2-oxo-2-(phenylamino)ethyl)-1-naphthamide(7a-1)

The product was obtained as a white solid; yield: $76.2 \%$; mp: $143.3-147.8^{\circ} \mathrm{C} .{ }^{1} \mathrm{H}$ NMR $\left(500 \mathrm{MHz}, \mathrm{CDCl}_{3}\right) \delta 8.95(\mathrm{~s}, 1 \mathrm{H}), 8.29-7.79(\mathrm{~m}, 4 \mathrm{H}), 7.55(\mathrm{dd}, J=17.2,9.9$ $\mathrm{Hz}, 4 \mathrm{H}), 7.44-7.29$ (m, 3H), 7.12 (dd, $J=22.1,6.7 \mathrm{~Hz}, 1 \mathrm{H}), 3.27$ (s, 2H), 2.94 (s, $3 \mathrm{H}) .{ }^{13} \mathrm{C} \mathrm{NMR}\left(126 \mathrm{MHz}, \mathrm{CDCl}_{3}\right) \delta 172.50,166.79,137.90,133.44,133.32,129.74$, $128.99,128.51,127.56,126.65,125.14,124.71,124.30,124.19,119.93,52.87,38.75$. ESI-MS m/z: $405[\mathrm{M}-\mathrm{H}]^{+}$. HPLC purity 99.2\%. Retention time: $4.7 \mathrm{~min}$, eluted with $20 \%$ purified water $/ 80 \%$ methanol.

N-methyl-N-(2-oxo-2-(phenylamino)ethyl)-1-naphthamide(7a-2)

The product was obtained as a white solid; yield: $73.2 \%$; mp: $147.6-151.4{ }^{\circ} \mathrm{C} .{ }^{1} \mathrm{H}$ NMR $\left(500 \mathrm{MHz}, \mathrm{CDCl}_{3}\right) \delta 7.88(\mathrm{t}, J=8.3 \mathrm{~Hz}, 2 \mathrm{H}), 7.77(\mathrm{~d}, J=8.3 \mathrm{~Hz}, 1 \mathrm{H}), 7.52-$ $7.45(\mathrm{~m}, 3 \mathrm{H}), 7.41-7.28(\mathrm{~m}, 6 \mathrm{H}), 7.00(\mathrm{~s}, 1 \mathrm{H}), 4.51(\mathrm{~d}, J=5.3 \mathrm{~Hz}, 2 \mathrm{H}), 3.25(\mathrm{~s}, 2 \mathrm{H})$, $2.92(\mathrm{~s}, 3 \mathrm{H}) .{ }^{13} \mathrm{C} \mathrm{NMR}\left(126 \mathrm{MHz}, \mathrm{CDCl}_{3}\right) \delta 171.98,168.53,138.07,133.40,133.38$, $129.59,129.37,128.78,128.44,127.74,127.54,127.35,126.53,125.07,124.66$, 124.06, 51.99, 43.54, 38.53. ESI-MS m/z: $405[\mathrm{M}-\mathrm{H}]^{+}$. HPLC purity $99.2 \%$. Retention time: 4.7 min, eluted with $20 \%$ purified water $/ 80 \%$ methanol.

N-methyl-N-(2-oxo-2-(phenylamino)ethyl)-2-naphthamide(7b-1)

The product was obtained as a white solid; yield: $76.1 \%$; mp: $141.6-146.1{ }^{\circ} \mathrm{C} .{ }^{1} \mathrm{H}$ NMR $\left(500 \mathrm{MHz}, \mathrm{CDCl}_{3}\right) \delta 8.98(\mathrm{~s}, 1 \mathrm{H}), 8.01(\mathrm{~s}, 1 \mathrm{H}), 7.93-7.84(\mathrm{~m}, 3 \mathrm{H}), 7.57(\mathrm{~d}, J$ $=6.0 \mathrm{~Hz}, 4 \mathrm{H}), 7.33(\mathrm{t}, J=7.8 \mathrm{~Hz}, 3 \mathrm{H}), 7.12(\mathrm{~s}, 1 \mathrm{H}), 3.53(\mathrm{~s}, 2 \mathrm{H}), 3.22(\mathrm{~s}, 3 \mathrm{H}) .{ }^{13} \mathrm{C}$ NMR $\left(126 \mathrm{MHz}, \mathrm{CDCl}_{3}\right) \delta 173.07,167.13,137.90,134.17,132.56,129.05,128.56$, $128.50,127.87,127.57,126.95,124.31,119.92,54.27,39.38$. ESI-MS m/z: 405 $[\mathrm{M}-\mathrm{H}]^{+}$. HPLC purity $99.2 \%$. Retention time: $4.7 \mathrm{~min}$, eluted with $20 \%$ purified water $/ 80 \%$ methanol.

N-(2-(benzylamino)-2-oxoethyl)-N-methyl-2-naphthamide(7b-2)

The product was obtained as a white solid; yield: $69.7 \%$; mp: $146.2-149.6{ }^{\circ} \mathrm{C} .{ }^{1} \mathrm{H}$ NMR $\left(500 \mathrm{MHz}, \mathrm{CDCl}_{3}\right) \delta 7.89(\mathrm{~d}, J=18.5 \mathrm{~Hz}, 4 \mathrm{H}), 7.60-7.42(\mathrm{~m}, 3 \mathrm{H}), 7.42-$ 
$7.26(\mathrm{~m}, 5 \mathrm{H}), 7.01(\mathrm{~s}, 1 \mathrm{H}), 4.49(\mathrm{~d}, J=10.3 \mathrm{~Hz}, 2 \mathrm{H}), 3.49(\mathrm{~s}, 2 \mathrm{H}), 3.16(\mathrm{~s}, 3 \mathrm{H}) .{ }^{13} \mathrm{C}$ NMR $\left(126 \mathrm{MHz}, \mathrm{CDCl}_{3}\right) \delta 172.56,168.74,138.15,133.87,132.64,128.77,128.48$, 127.82, 127.54, 127.40, 126.85, 124.16, 52.68, 43.44, 39.18. ESI-MS m/z: 405 $[\mathrm{M}-\mathrm{H}]^{+}$. HPLC purity $99.2 \%$. Retention time: $4.7 \mathrm{~min}$, eluted with $20 \%$ purified water $/ 80 \%$ methanol.

4.6.5N-methyl-N-(2-oxo-2-(phenylamino)ethyl)-2,3-dihydrobenzo[b][1,4]dioxine-5-c arboxamide $(7 c-1)$

The product was obtained as a white solid; yield: $77.2 \%$; mp: $133.3-136.4{ }^{\circ} \mathrm{C} .{ }^{1} \mathrm{H}$ NMR $\left(500 \mathrm{MHz}, \mathrm{CDCl}_{3}\right) \delta 8.58(\mathrm{~s}, 1 \mathrm{H}), 7.52(\mathrm{~d}, J=8.1 \mathrm{~Hz}, 2 \mathrm{H}), 7.34(\mathrm{t}, J=7.8 \mathrm{~Hz}$, 2H), $7.13(\mathrm{t}, J=7.4 \mathrm{~Hz}, 1 \mathrm{H}), 6.97-6.88(\mathrm{~m}, 3 \mathrm{H}), 4.30(\mathrm{~m}, 4 \mathrm{H}), 3.21(\mathrm{~s}, 2 \mathrm{H}), 3.05(\mathrm{~s}$, $3 \mathrm{H}) .{ }^{13} \mathrm{C}$ NMR $\left(126 \mathrm{MHz}, \mathrm{CDCl}_{3}\right) \delta 169.56,166.72,143.66,139.65,137.68,129.25$, 129.03, 124.69, 124.52, 122.18, 120.13, 119.82, 119.50, 118.95, 64.90, 64.16, 52.87, 37.76. ESI-MS m/z: $405[\mathrm{M}-\mathrm{H}]^{+}$. HPLC purity 99.2\%. Retention time: $4.7 \mathrm{~min}$, eluted with $20 \%$ purified water $/ 80 \%$ methanol.

$\mathrm{N}$-(2-(benzylamino)-2-oxoethyl)-N-methyl-2,3-dihydrobenzo[b][1,4]dioxine-5-carbox amide $(7 c-2)$

The product was obtained as a white solid; yield: $70.2 \%$; mp: $141.3-144.9{ }^{\circ} \mathrm{C} .{ }^{1} \mathrm{H}$ NMR (500 MHz, $\left.\mathrm{CDCl}_{3}\right) \delta 7.37-7.30(\mathrm{~m}, 2 \mathrm{H}), 7.27(\mathrm{~d}, J=5.4 \mathrm{~Hz}, 3 \mathrm{H}), 7.17-6.70$ $(\mathrm{m}, 4 \mathrm{H}), 4.47(\mathrm{~d}, J=5.2 \mathrm{~Hz}, 2 \mathrm{H}), 4.28(\mathrm{~m}, 4 \mathrm{H}), 3.48(\mathrm{~s}, 2 \mathrm{H}), 3.12(\mathrm{~s}, 3 \mathrm{H}) .{ }^{13} \mathrm{C} \mathrm{NMR}$ $\left(126 \mathrm{MHz}, \mathrm{CDCl}_{3}\right) \delta 168.92,168.10,143.44,139.28,137.97,128.93,128.79,128.13$, 128.01, 127.64, 124.93, 122.27, 119.54, 118.74, 64.12, 64.04, 51.40, 43.72, 37.55. ESI-MS m/z: $405[\mathrm{M}-\mathrm{H}]^{+}$. HPLC purity $99.2 \%$. Retention time: $4.7 \mathrm{~min}$, eluted with $20 \%$ purified water $/ 80 \%$ methanol.

$\mathrm{N}$-methyl-N-(2-oxo-2-(phenylamino)ethyl)-2,3-dihydrobenzo[b][1,4]dioxine-6-carbo xamide $(7 d-1)$

The product was obtained as a white solid; yield: $68.3 \%$; mp: $140.3-142.8^{\circ} \mathrm{C} .{ }^{1} \mathrm{H}$ NMR $\left(500 \mathrm{MHz}, \mathrm{CDCl}_{3}\right) \delta 9.01(\mathrm{~s}, 1 \mathrm{H}), 7.55(\mathrm{~d}, J=7.7 \mathrm{~Hz}, 2 \mathrm{H}), 7.33(\mathrm{t}, J=7.5 \mathrm{~Hz}$, 2H), $7.18-6.96(\mathrm{~m}, 3 \mathrm{H}), 6.90(\mathrm{~d}, J=8.0 \mathrm{~Hz}, 1 \mathrm{H}), 4.29(\mathrm{~m}, 4 \mathrm{H}), 3.49$ (s, 2H), 3.19 (s, $3 \mathrm{H}) .{ }^{13} \mathrm{C} \mathrm{NMR}\left(126 \mathrm{MHz}, \mathrm{CDCl}_{3}\right) \delta 172.45,167.16,145.72,143.36,137.90,130.84$, 129.01, 127.32, 127.30, 124.34, 121.43, 119.87, 117.32, 64.50, 64.26, 54.60, 39.36. ESI-MS m/z: $405[\mathrm{M}-\mathrm{H}]^{+}$. HPLC purity $99.2 \%$. Retention time: $4.7 \mathrm{~min}$, eluted with $20 \%$ purified water $/ 80 \%$ methanol.

$\mathrm{N}$-(2-(benzylamino)-2-oxoethyl)-N-methyl-2,3-dihydrobenzo[b][1,4]dioxine-6-carbox amide(7d-2)

The product was obtained as a white solid; yield: $70.2 \%$; mp: $144.5-147.4{ }^{\circ} \mathrm{C} .{ }^{1} \mathrm{H}$ NMR (500 MHz, $\left.\mathrm{CDCl}_{3}\right) \delta 7.36-7.32(\mathrm{~m}, 2 \mathrm{H}), 7.30(\mathrm{~s}, 3 \mathrm{H}), 6.90-6.84(\mathrm{~m}, 4 \mathrm{H})$, $4.49(\mathrm{~d}, J=5.9 \mathrm{~Hz}, 2 \mathrm{H}), 4.03(\mathrm{~m}, 4 \mathrm{H}), 3.13(\mathrm{~s}, 2 \mathrm{H}), 2.96(\mathrm{~s}, 3 \mathrm{H}) .{ }^{13} \mathrm{C} \mathrm{NMR}(126 \mathrm{MHz}$, $\left.\mathrm{CDCl}_{3}\right) \delta 168.86,168.24,143.35,139.55,137.92,129.77,129.31,128.74,127.53$, 124.23, 122.21, 119.98, 118.38, 64.48, 64.25, 50.87, 43.40, 37.33. ESI-MS m/z: 405 $[\mathrm{M}-\mathrm{H}]^{+}$. HPLC purity $99.2 \%$. Retention time: $4.7 \mathrm{~min}$, eluted with $20 \%$ purified water $/ 80 \%$ methanol.

\section{Construction of the CASE homology model}

In the process, the amino acid sequence of Candida albicans squalene epoxidase was selected as research object, and these protein crystal structures with homologous 
sequences were searched and aligned in the PDB database. Subsequently, the structure and sequence of the template protein with highest homology was loaded into the operation interface, and its homologous sequences was further confirmed by align sequences. Finally, the homology model was constructed by the Build Homology Model module, and its reliability was further evaluated using the RAMPAGE server (http://services.mbi. ucla.edu/SAVES/), and the result was shown in Ramachandran plots. At the same time, the compatibility of the 3D model with its own amino acid 1D sequence was examined using Verify 3D.

\section{Protein structure preparation and ligand preparation}

Protein structure preparation: The homology model of SE (Candida albicans) were processed with the protein preparation module in the DS 3.0. The program performs the following steps: added all hydrogen atoms, optimized the side chain of amino acid residues, completed the loop area and protonated the structure at the specified $\mathrm{pH}$ value. Ligand preparation: target compounds were optimized using LigPrep, which included adding all hydrogen atoms, adjusting the bond order and atom types, adjusting the appropriate protonation and generating the conformations with low energy.

\section{Docking simulations}

In order to evaluate the binding modes between SE inhibitors and target enzyme (SE), the molecular docking was performed using CDOCKER, which is the semi-flexible docking program. First, the position of the co-crystalline ligand (EKV 497 in CA-SE) was defined as the active site (X: -19.799, Y:73.637, Z: 55.144), and the radius of the active sphere was set to $9 \AA$. Then, the target compounds were docked into the active site using the CDOCKER program. The maximum save conformation was set to 10 , and all other options were kept as the default settings during the docking process. Finally, the docking result was obtained.

Construction of pharmacophore model based on CASE receptor structure

Pharmacophore model based on receptor structure can directly obtain the structural features with high matching to the active cavity. The pharmacophore features of CASE with ligand (naftifine) were constructed using the method of Receptor-Ligand pharmacophore Generation (SBP) model. Frist, the Binding Sites Sphere was defined from this ligand, and the parameter was set to 9, which comprised all the key amino acid residues. Then, the Interaction Generation Protocol Implemented in DS was used to produce the HBA, HBD and HY features set based on the active site residues inside the sphere. Finally, the feature sets were clustered, and important pharmacophore features were retained by analyzing the characteristics of active sites.

\section{Antifungal activity test in vitro}

The antifungal activity of target compounds was tested using the standard guidelines, which described in the National Committee for Clinical Laboratory Standards (NCCLS), and the in vitro minimum inhibitory concentrations (MIC) value is defined as the lowest concentration of antifungal inhibitor with inhibitory effect. Naftifine was selected as positive control drugs. In the study, the pathogenic fungi were cultured using the Sabouraud medium, and the fungal solution was added into 24-well culture plate. The different concentration of target compounds solution was 
serially dripped into the growth medium with different strains, and the concentration gradient was set to $0.0625,0.125,0.5,1,2,4,8$ and $16 \mu \mathrm{g} / \mathrm{mL}$, respectively. Subsequently, they were statically cultured in a $35{ }^{\circ} \mathrm{C}$ incubator, and the MIC results were observed and recorded.

The Experiment of Transmission Electron Microscopy (TEM)

According to the test protocol of NCCLS, the concentration of target compound $7 \mathrm{a}-2$ in the bacterial solution was adjusted to $4 \mathrm{ug} / \mathrm{mL}$, and they were incubated at 35 ${ }^{\circ} \mathrm{C}$. Subsequently, the bacterial solution was sampled at different time points (48h), and they were fixed in $4{ }^{\circ} \mathrm{C}$ refrigerators with $3 \%$ glutaric acid, washed with PBS solution. Finally, these samples were further stained with uranium osmium for $30 \mathrm{~min}$, they were observed using transmission electron microscopy.

The analysis experiment of the components of C. albicans cells

In this process, Candida albicans (ATCC SC5314) was selected as the test strain. Naftifine was purchased as the positive control drug. In the study, the concentration of target compounds was set to $0.125,0.5$ and $4 \mu \mathrm{g} / \mathrm{mL}$. After 16 hours of cultivation, the different groups of wet bacteria are concentrated and washed with PBS, and the sterol component was extracted using petroleum ether. The solvent was removed under reduced pressure. Finally, the product was dissolved in methanol solution $(10 \mathrm{~mL})$, filtered and detected by LC-MS. The chromatographic conditions were selected with Phenomenex Luna $\mathrm{C}_{18}(2.50 \mathrm{~mm} \times 4.6 \mathrm{~mm}, 5 \mu \mathrm{m})$ column. The mobile phase was methanol-water (98:2), the flow rate was $1 \mathrm{~mL} / \mathrm{min}^{-1}$, and the detection wavelength was $210 \mathrm{~nm}$. The peak area ratio of each component is calculated.

\section{The structure spectra of target compound}

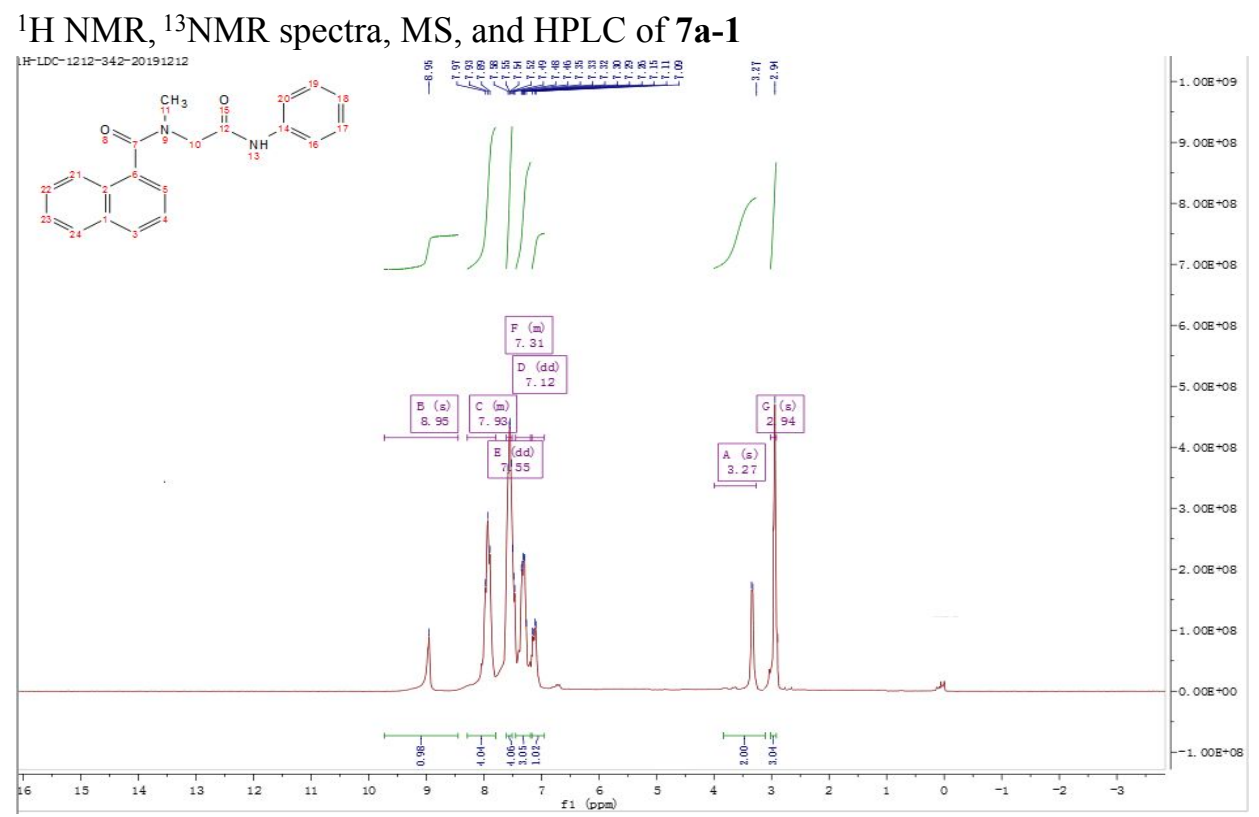



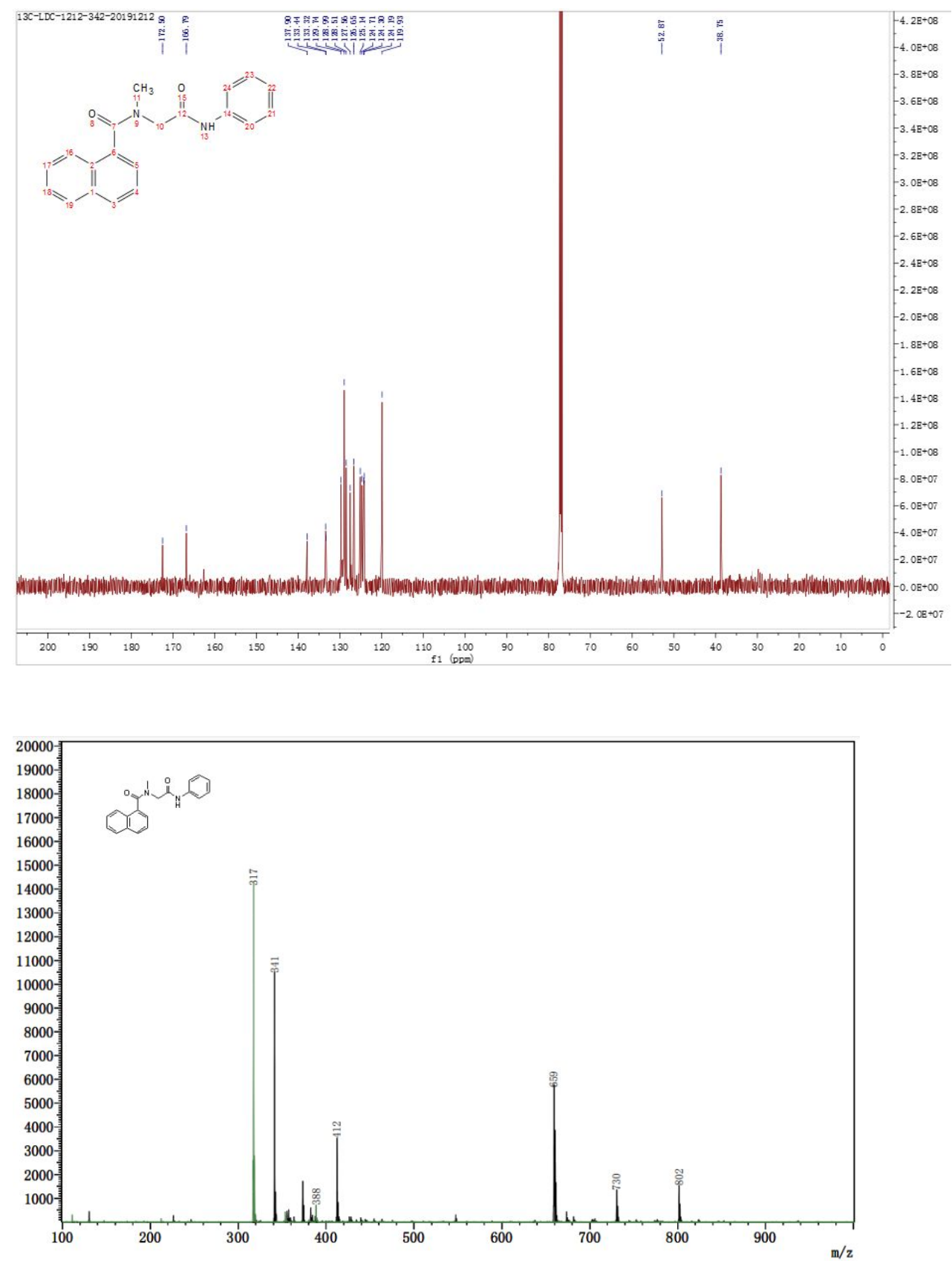


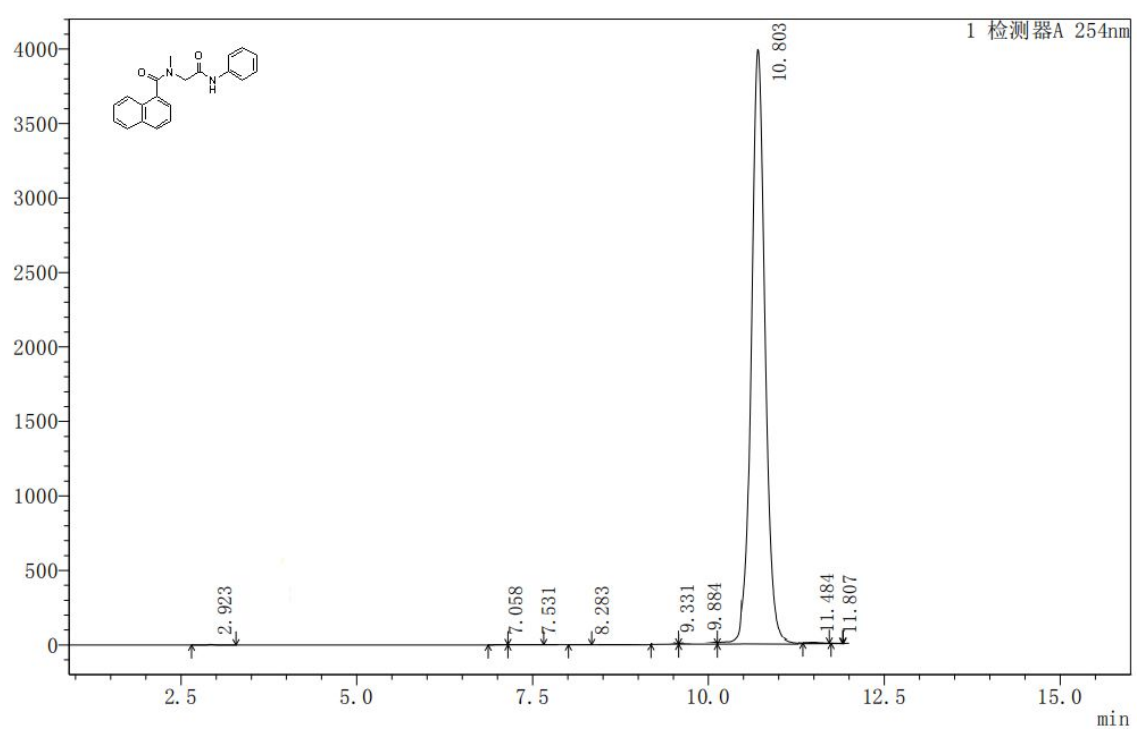

${ }^{1} \mathrm{H}$ NMR, ${ }^{13} \mathrm{NMR}$ spectra, MS, and HPLC of 7a-2

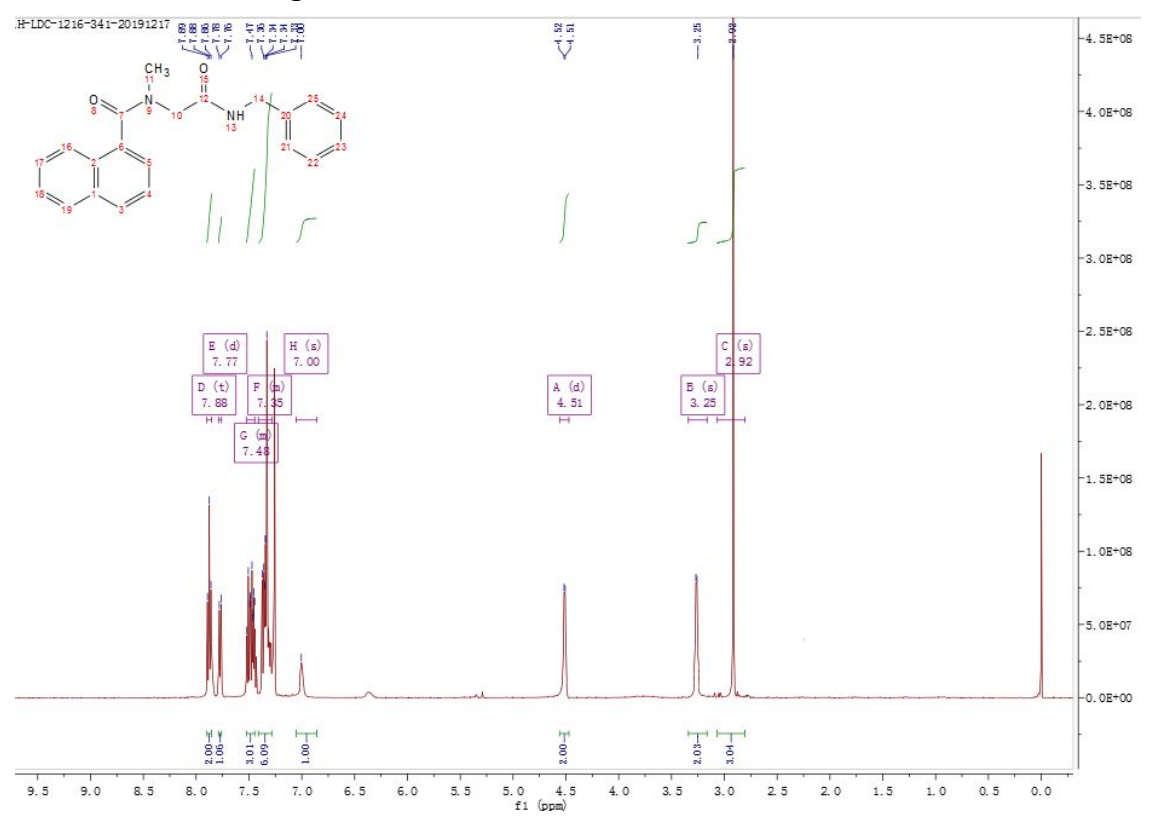



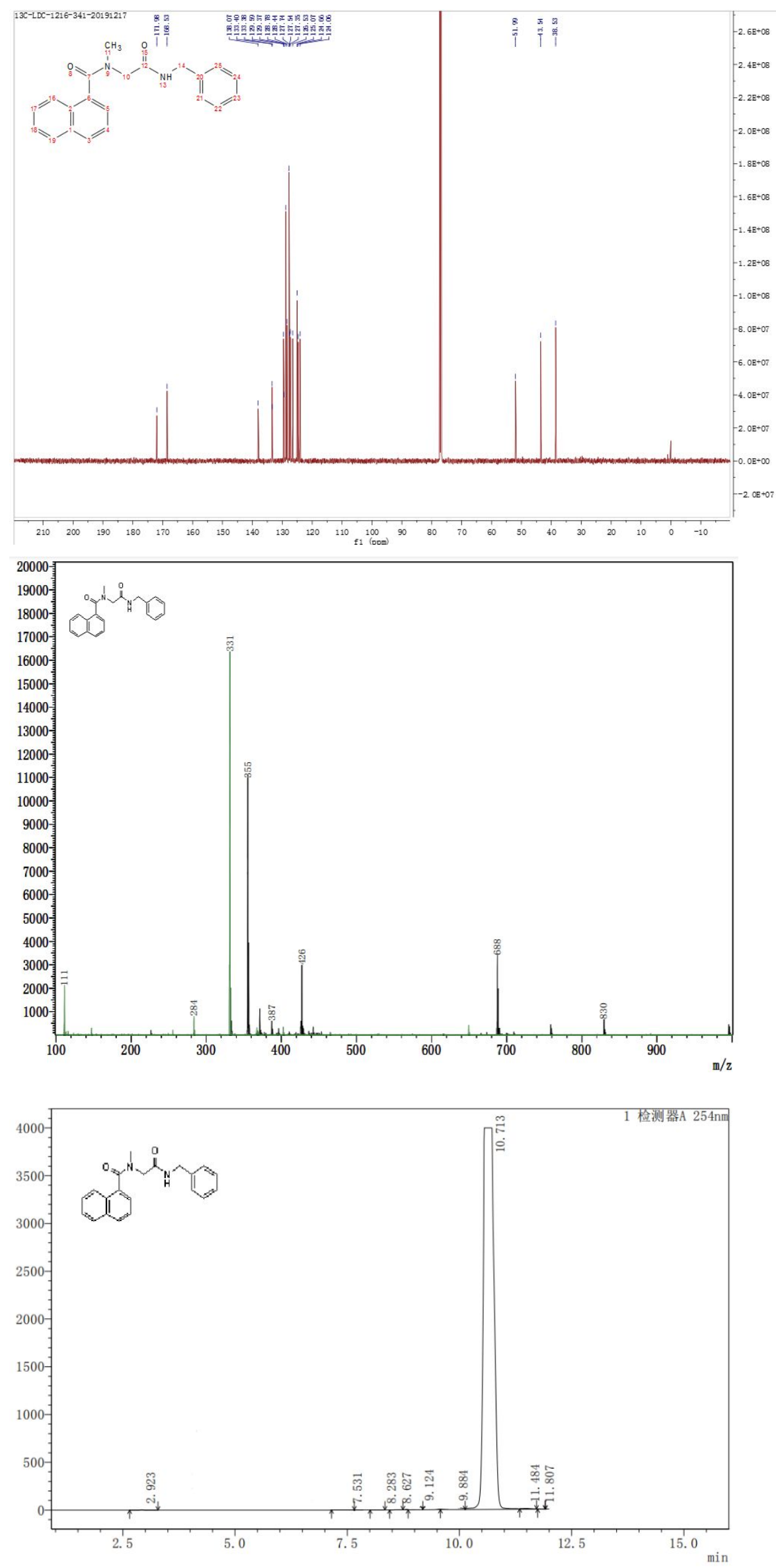
${ }^{1} \mathrm{H}$ NMR, ${ }^{13} \mathrm{NMR}$ spectra, MS, and HPLC of 7b-1
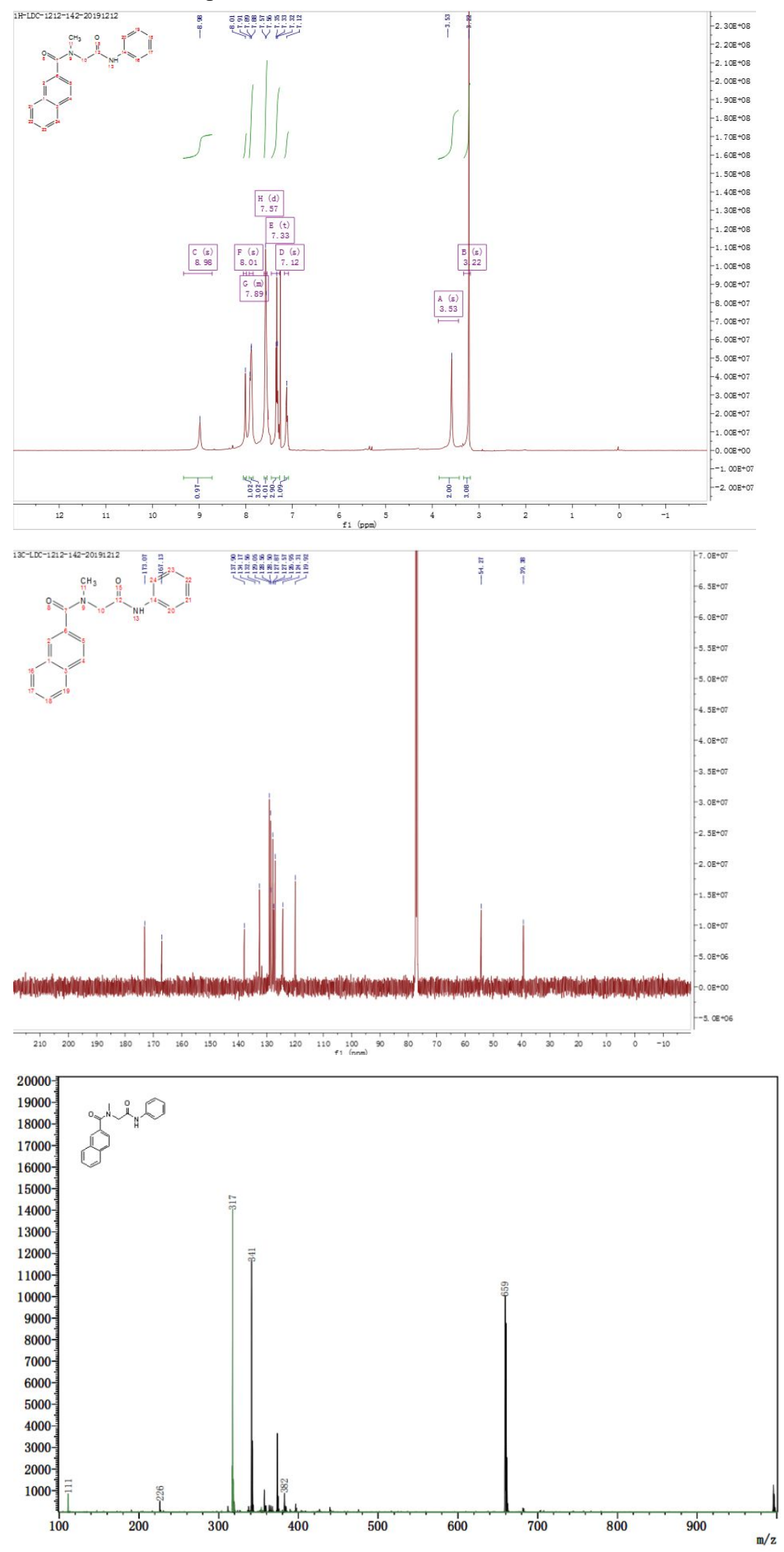


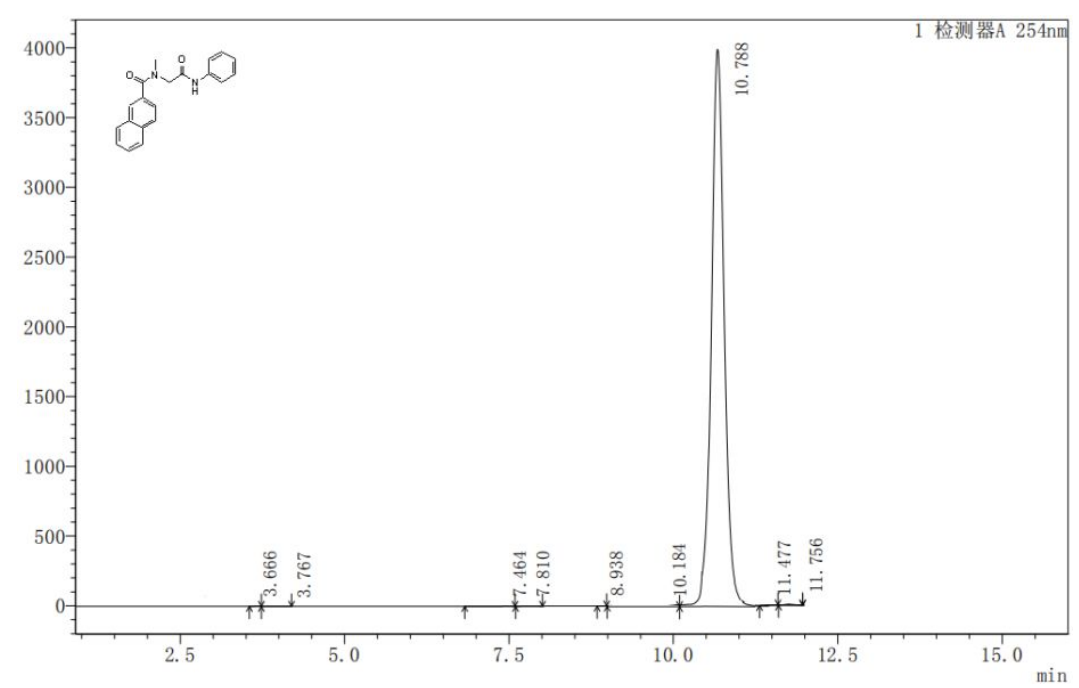

${ }^{1} \mathrm{H}$ NMR, ${ }^{13}$ NMR spectra, MS, and HPLC of 7b-2
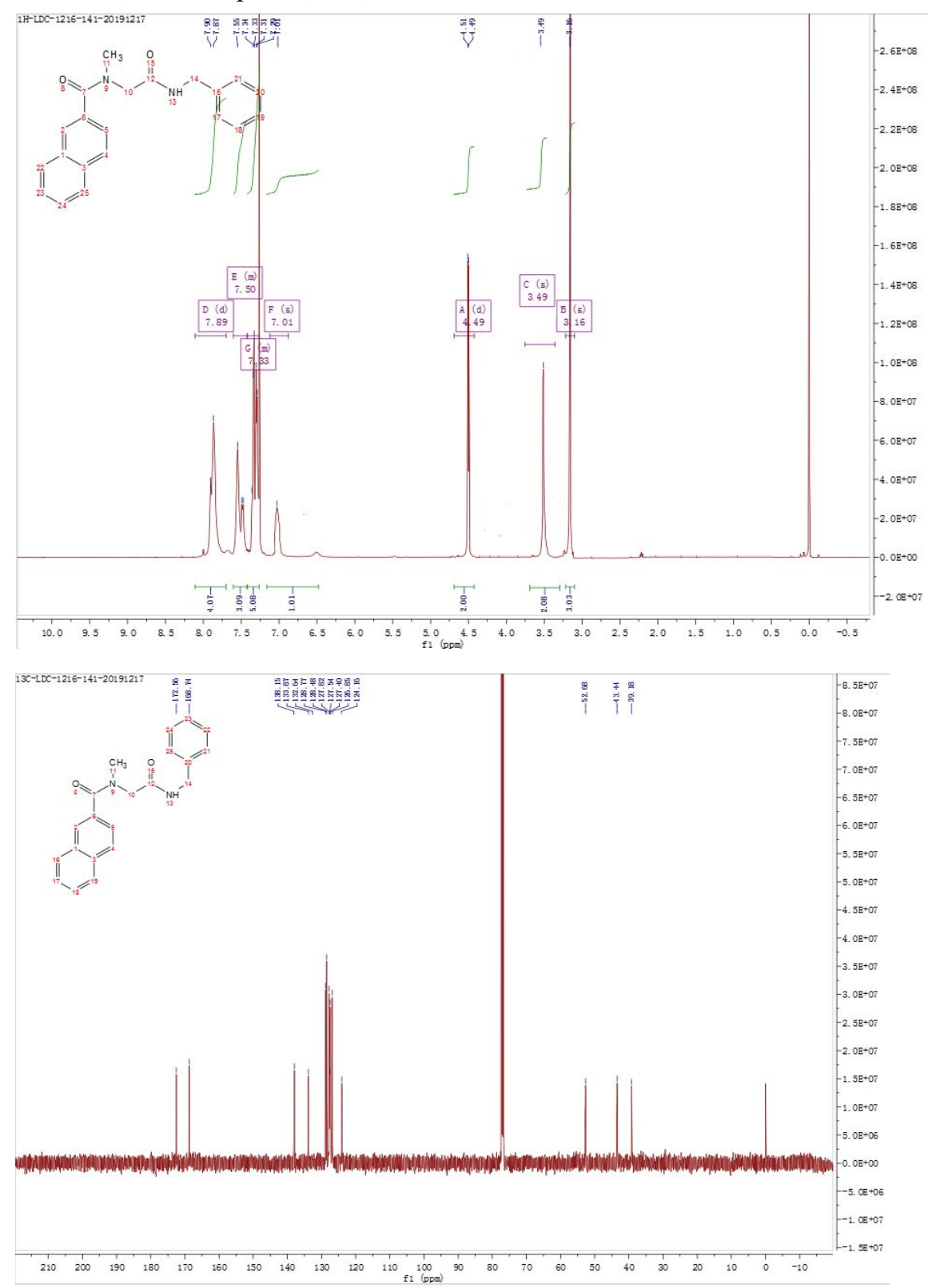

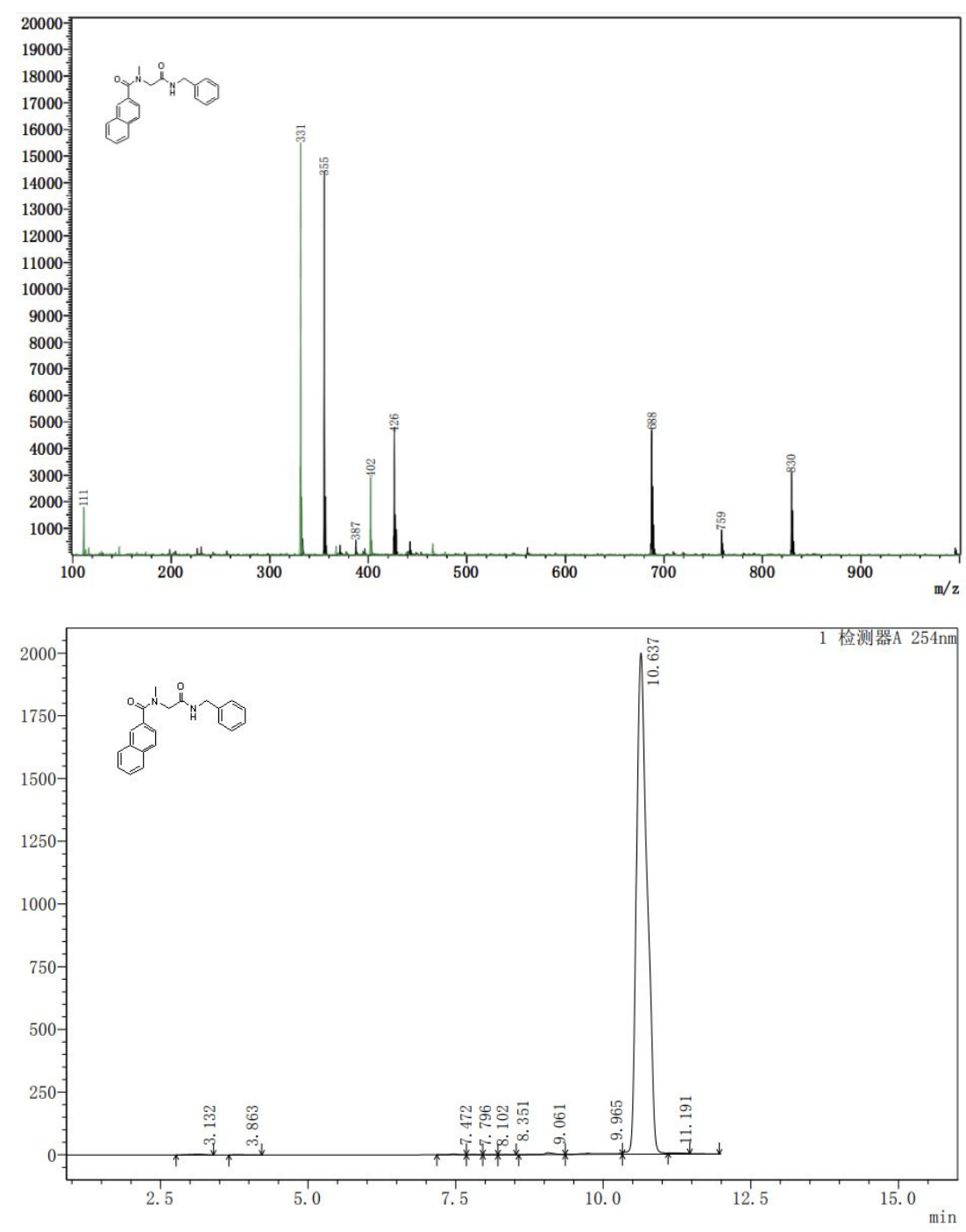

${ }^{1} \mathrm{H}$ NMR, ${ }^{13} \mathrm{NMR}$ spectra, MS, and HPLC of 7c-1

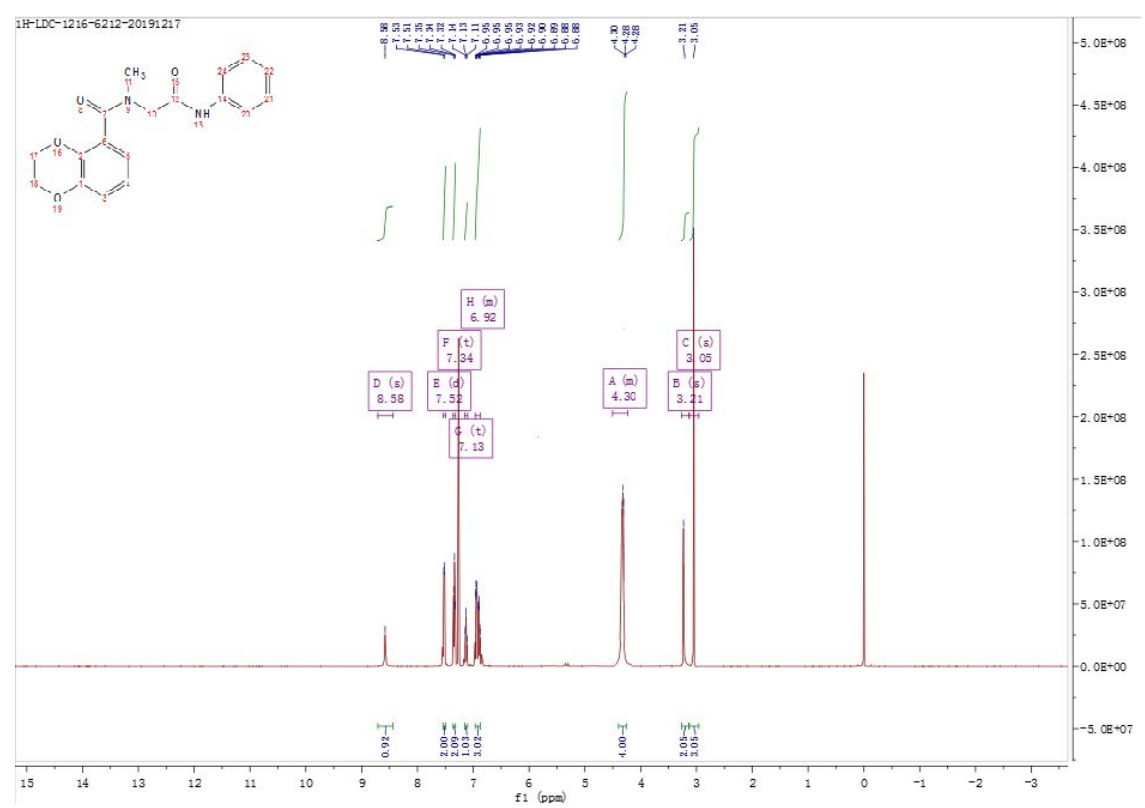



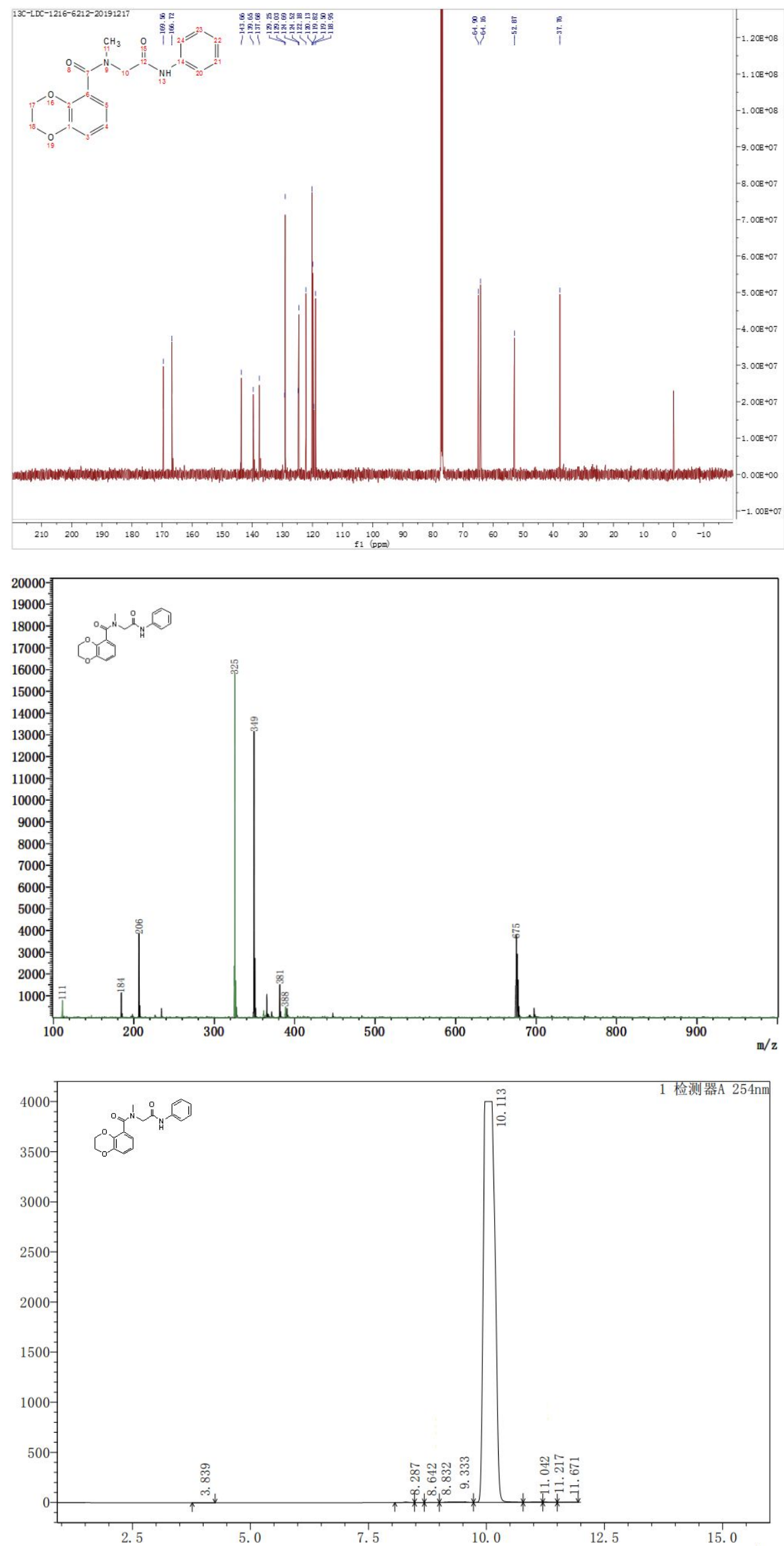
${ }^{1} \mathrm{H}$ NMR, ${ }^{13} \mathrm{NMR}$ spectra, MS, and HPLC of $\mathbf{7 c - 2}$
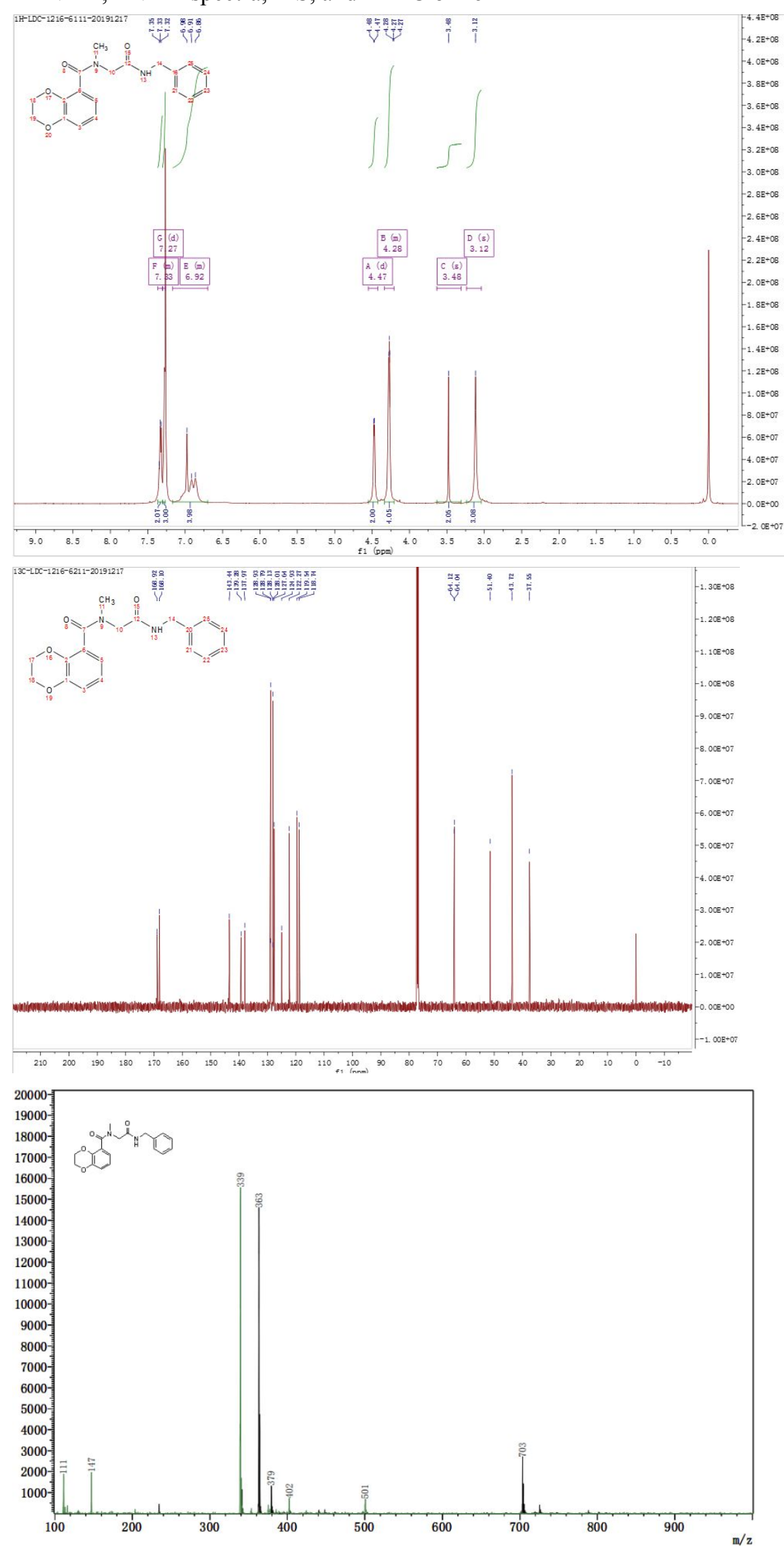


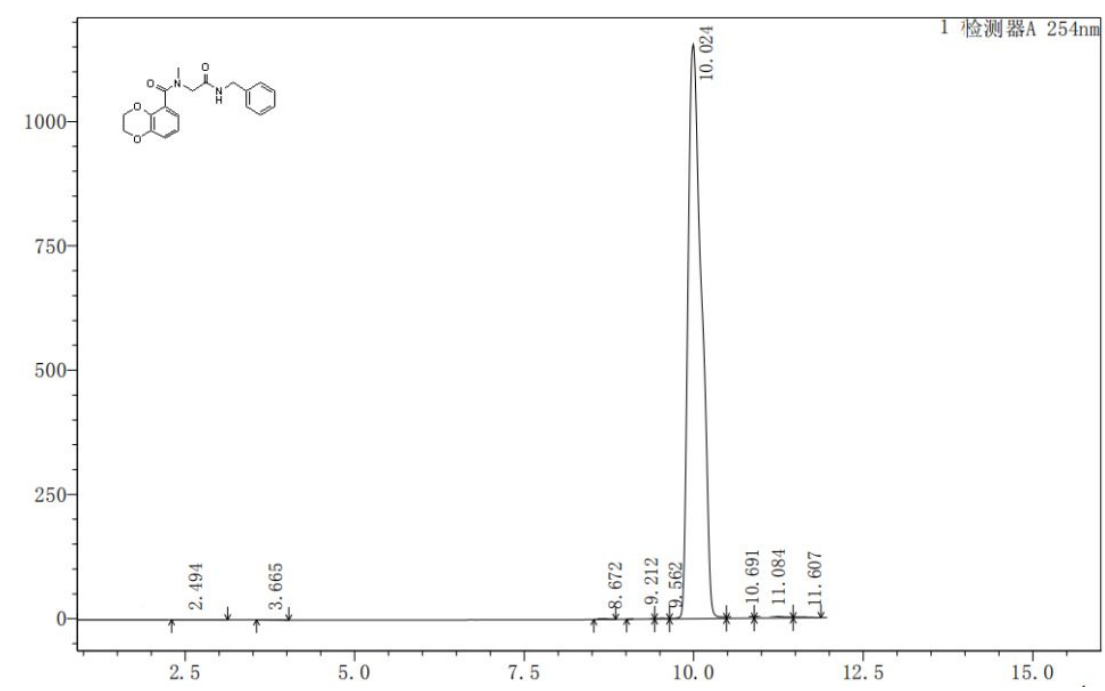

${ }^{1} \mathrm{H}$ NMR, ${ }^{13} \mathrm{NMR}$ spectra, MS, and HPLC of 7d-1
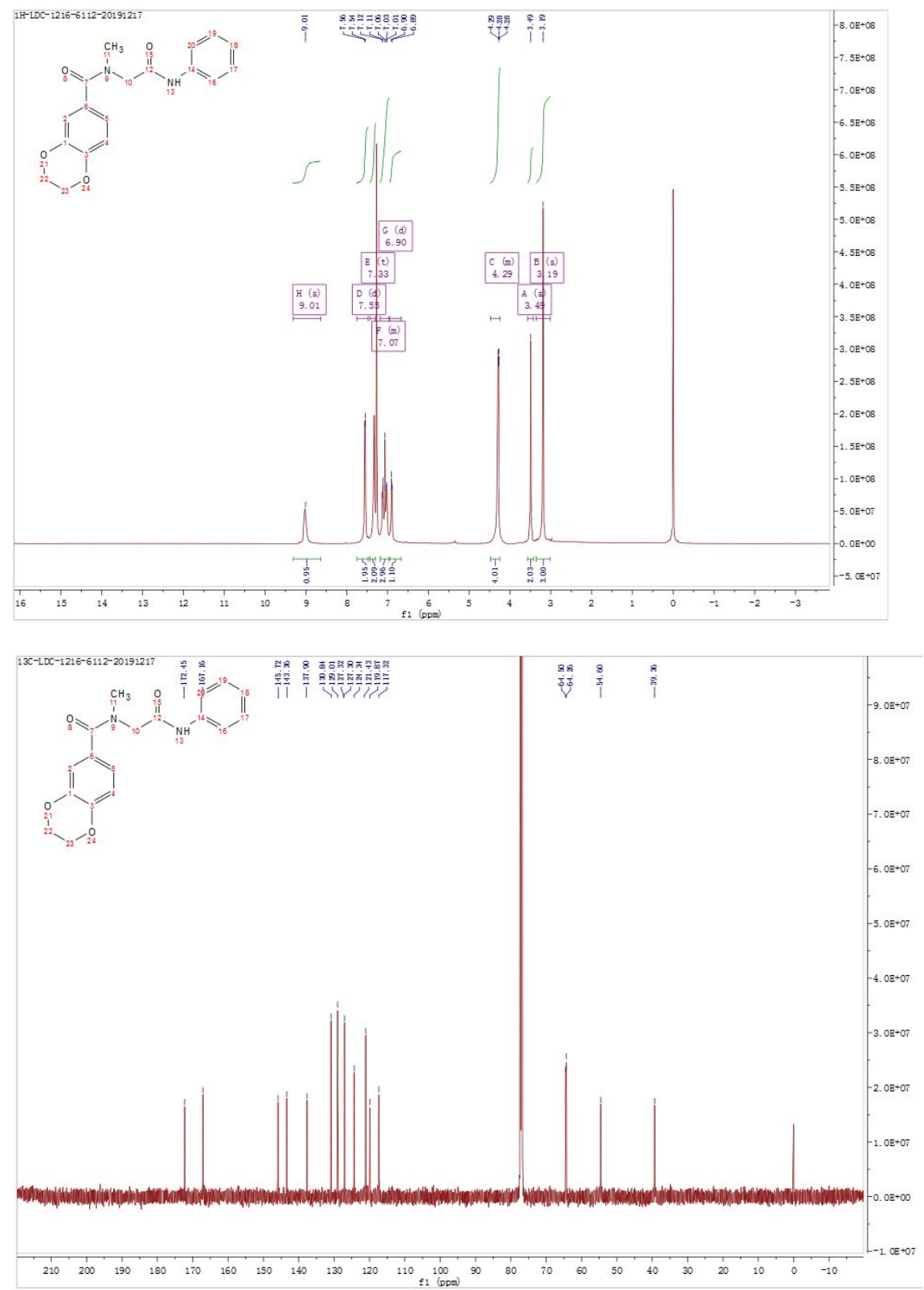

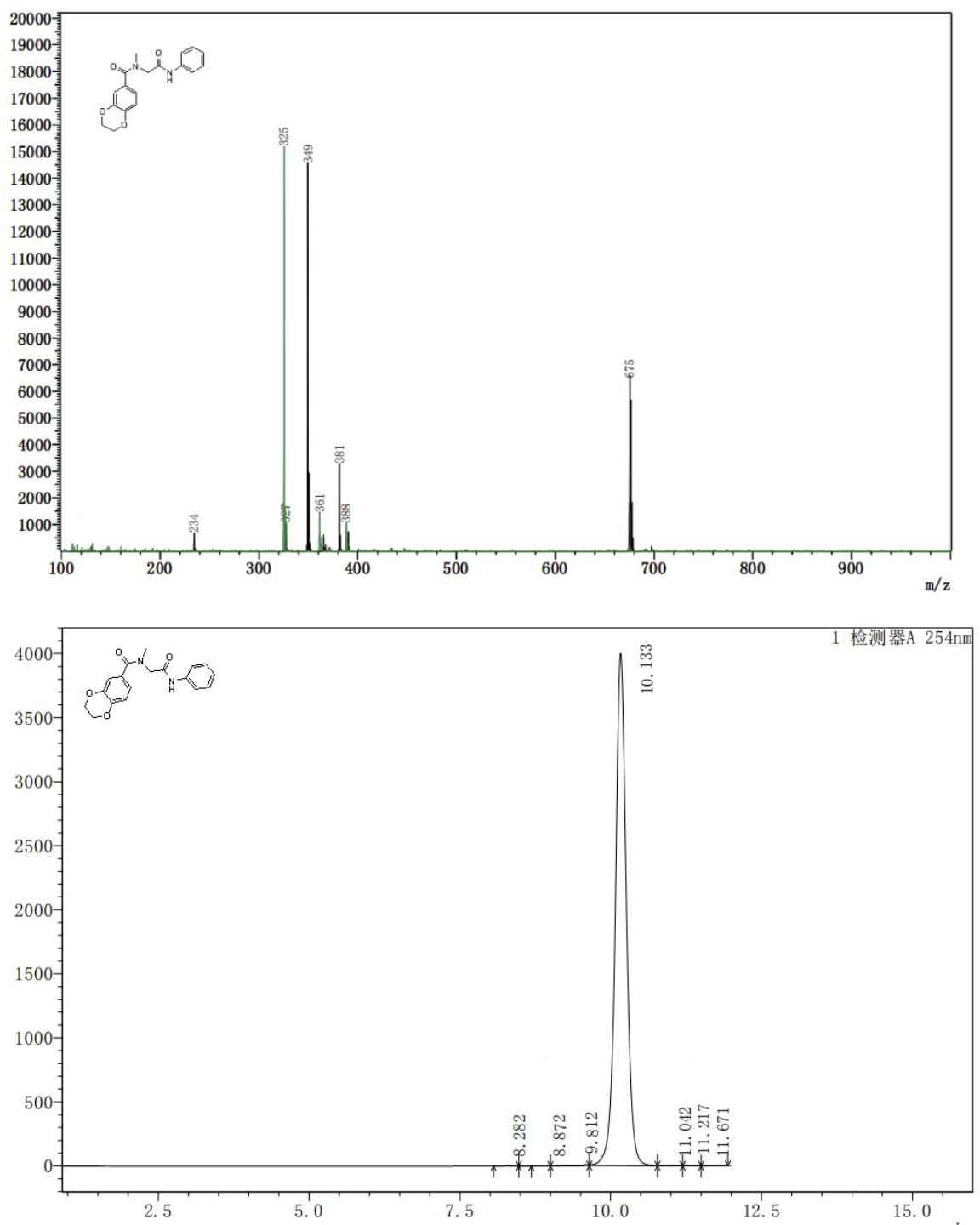

${ }^{1} \mathrm{H}$ NMR, ${ }^{13} \mathrm{NMR}$ spectra, MS, and HPLC of 7d-2

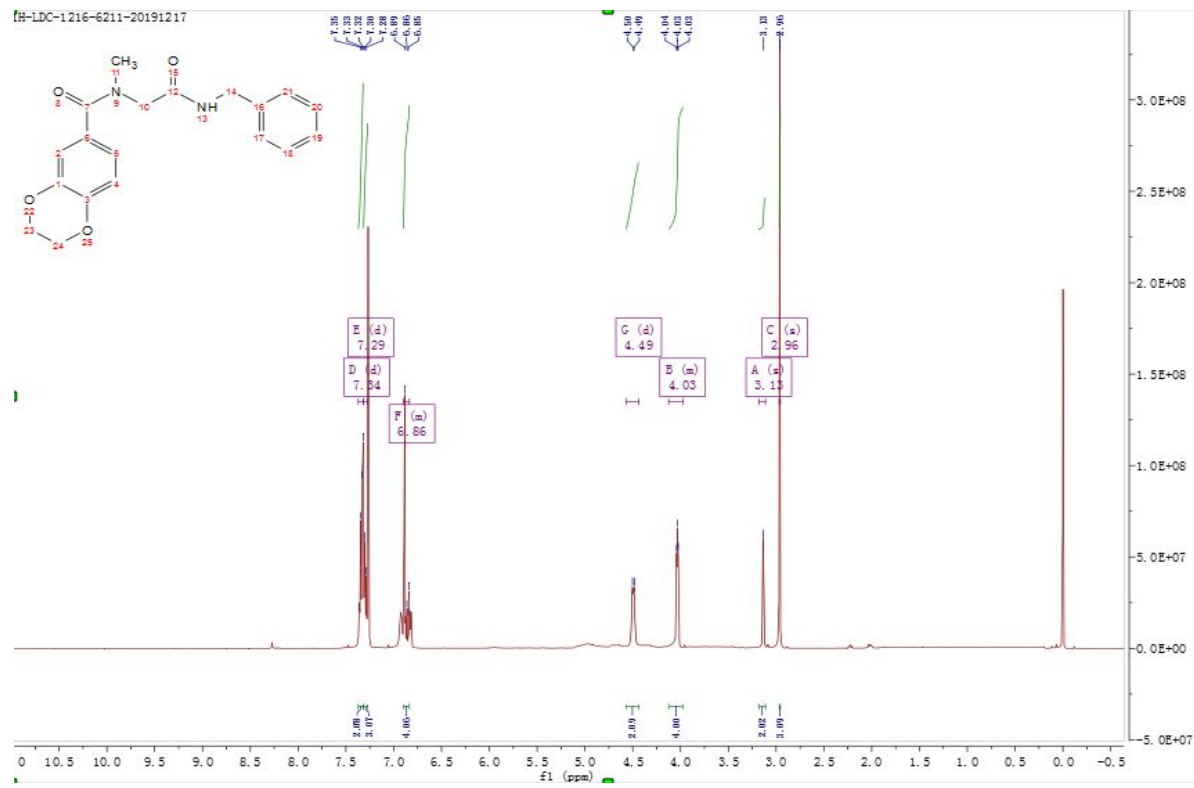




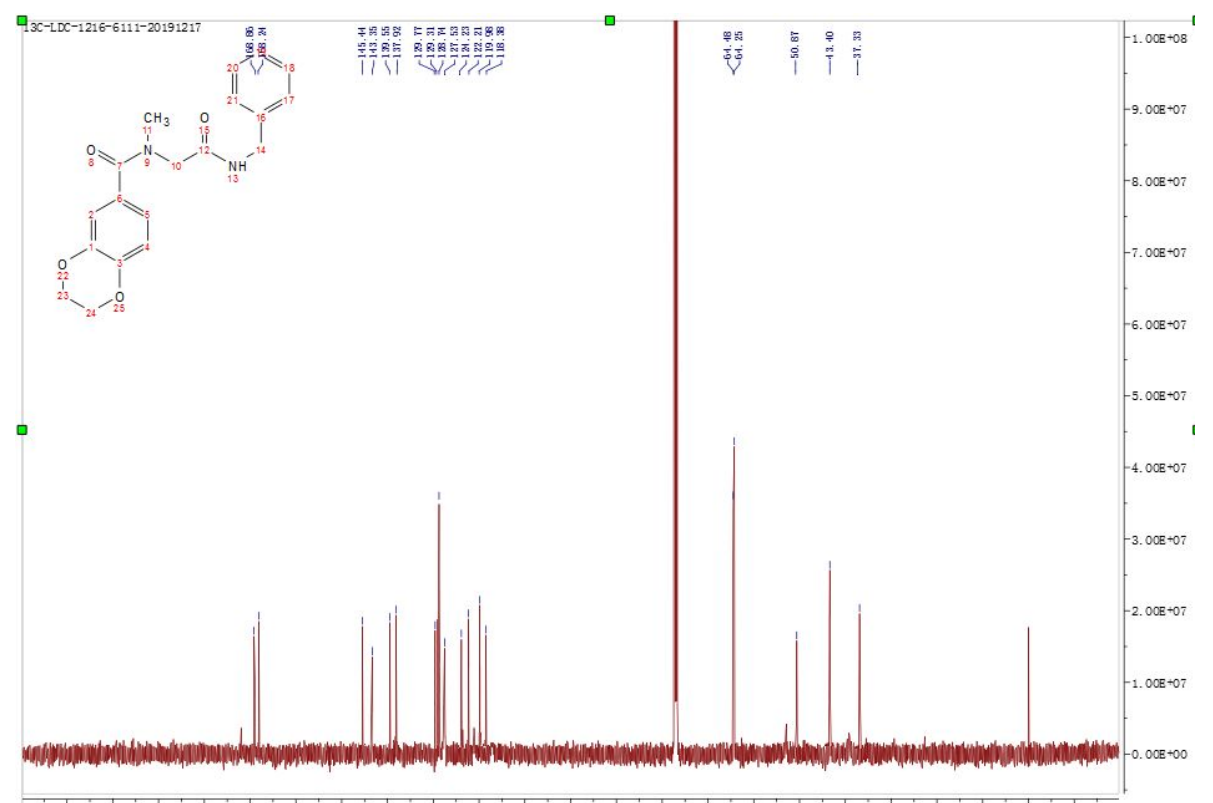

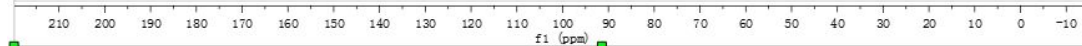
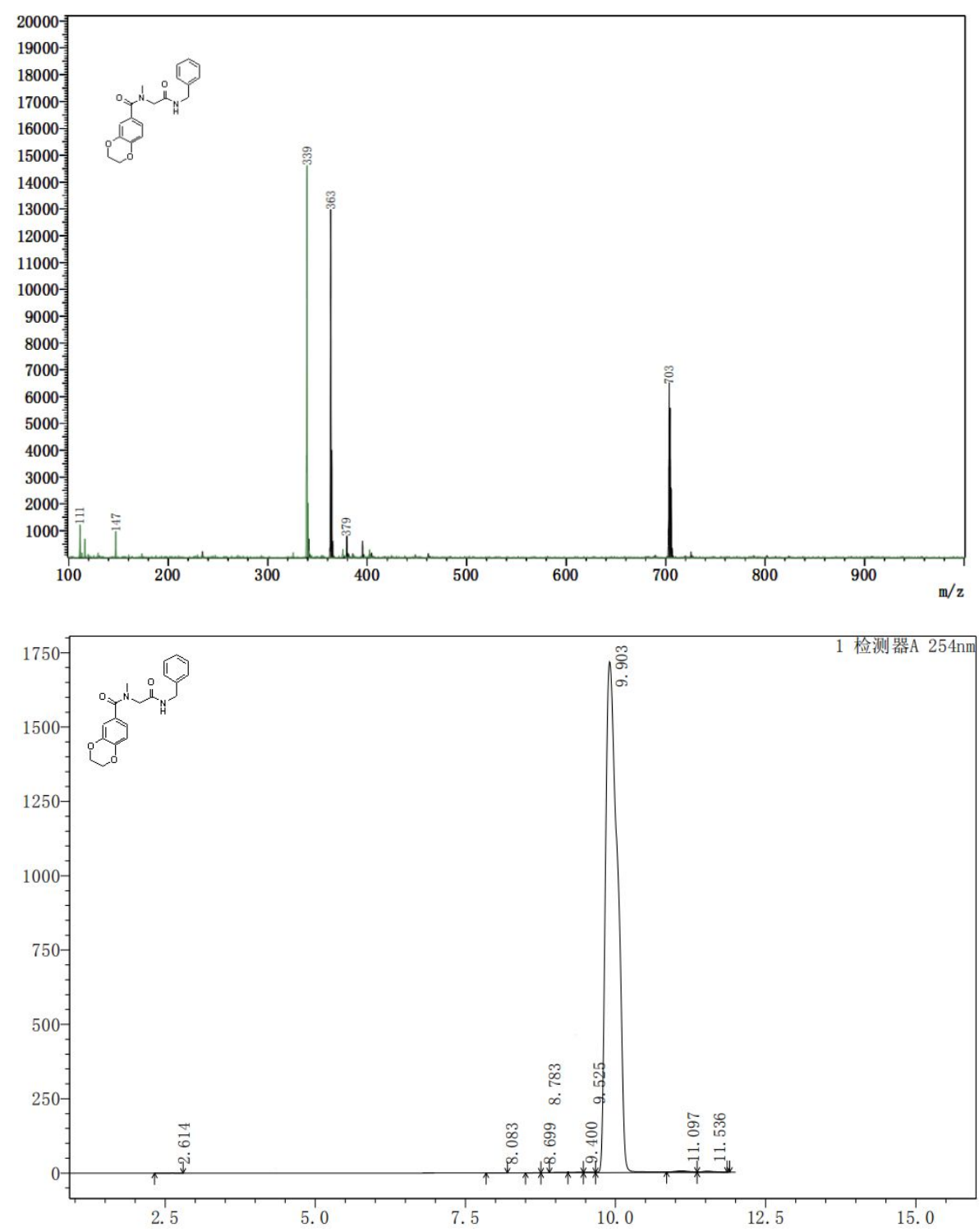


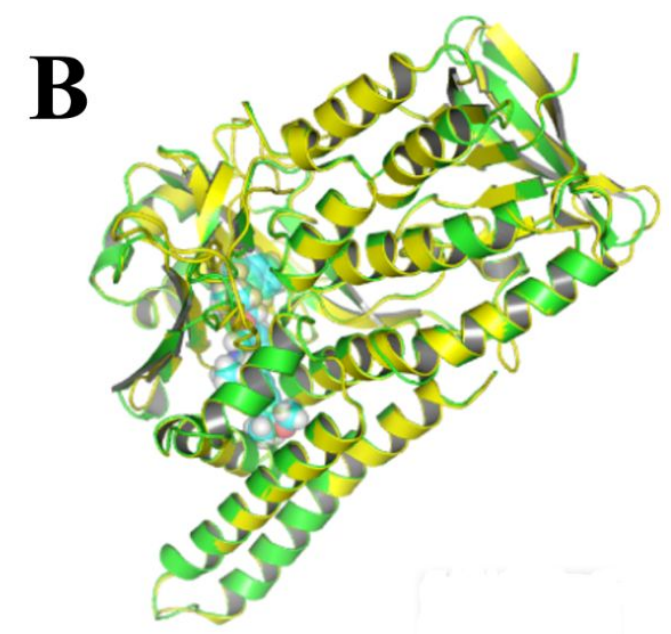

Figure 2.The superposition graph of CASE.003 (green) and template protein 6C6N (yellow). 